\title{
MENUMBUHKAN MINAT BERWIRAUSAHA MAHASISWA MELALUI PENDIDIKAN KEWIRAUSAHAAN BERBASIS CARING ECONOMICS
}

\author{
Indra Darmawan \\ Universitas Sanata Dharma, Indonesia \\ indradarmawanusd@gmail.com
}

\begin{abstract}
Abstrak: Penelitian ini bertujuan untuk menumbuhkan minat berwirausaha mahasiswa melalui pendidikan kewirausahan berbasis caring economics. Jenis penelitian yaitu kuasi eksperimen dengan subjek penelitiannya adalah mahasiswa yang menempuh Mata Kuliah Kewirausahaan. Hasil penelitian menunjukkan bahwa minat berwirausaha mahasiswa dapat ditumbuhkan melalui pendidikan kewirausahaan yang berbasis caring economics. Mahasiswa merasa terbantu untuk dapat menemukan potensi dirinya dan menumbuhkan rasa kepedulian kepada sesama dan lingkungan dalam semangat kerjasama dan gotong royong.

Kata kunci: Minat Berwirausaha, Pendidikan Kewirausahaan, Caring Economics
\end{abstract}

\section{STUDENTS' ENTREPRENEURIAL INTENTION IMPROVEMENT THROUGH ENTREPRENEURSHIP EDUCATION BASED ON CARING ECONOMICS}

\begin{abstract}
This study aims to improve students' entrepreneurial intention through entrepreneurship education based on caring economics. The type of research is quasiexperimental, with the research subjects being students taking Entrepreneurship Courses. The results showed that students' entrepreneurial intention could be improved through entrepreneurship education based on caring economics. Students feel helped to find their potential and foster a sense of concern for others and the environment in a spirit of cooperation and cooperation.
\end{abstract}

Keywords: Entrepreneurial Intention, Entrepreneurship Education, Caring Economics

\section{PENDAHULUAN}

Fenomena pengangguran lulusan pendidikan tinggi telah menjadi keprihatinan sejak lama. Umumnya para angkatan kerja yang termasuk dalam kategori usia muda mengharapkan mendapatkan pekerjaan sebagai pegawai negeri sipil atau sektor swasta yang menjanjikan begitu lulus dari dunia pendidikan. Hal ini disebabkan masih kentalnya cara berpikir praktis bahwa tujuan bersekolah adalah untuk memudahkan mencari pekerjaan.

Berdasarkan data Badan Pusat Statistik (BPS), angka pengangguran terbuka di Indonesia selama 10 tahun terakhir memang mengalami penurunan yaitu dari 7.244 .905 jiwa pada tahun 2014 turun menjadi 7.104.424 jiwa pada tahun 2019. Meski fakta berkurangnya angka pengangguran ini merupakan capaian yang positif, tetapi masalah pengangguran tetap menghantui Indonesia. Terlebih jika dilihat angka pengangguran lulusan sarjana pada tahun 2019 yang mencapai 746.354 jiwa atau sebesar 10,78 persen dari seluruh angka pengangguran terbuka di Indonesia.

Pada tahun 2025-2030 Indonesia mendapat bonus demografi, yakni suatu keadaan dengan jumlah penduduk produktif lebih besar daripada jumlah penduduk muda dan lanjut usia (lansia). Penduduk usia produktif yang tidak memiliki kesempatan kerja akan menjadi malapetaka bagi negara. Oleh sebab itu tantangan besar yang dihadapi adalah bagaimana mengupayakan agar sumberdaya manusia usia produktif yang berlimpah ini dapat ditransformasikan menjadi 
sumberdaya manusia yang memiliki kompetensi dan keterampilan melalui pendidikan agar tidak menjadi beban.

Salah satu cara untuk menekan angka pengangguran yang cukup tinggi di kalangan lulusan terdidik adalah dengan jalan menumbuhkan minat berwirausaha sedini mungkin. Minat berwirausaha ini dapat ditumbuhkan melalui jalur pendidikan kewirausahaan. Pendidikan kewirausahaan harus didesain secara khusus untuk memfasilitasi pembelajaran kewirausahaan pada usia muda. Kewirausahaan adalah seni yang bisa dipelajari dan dikembangkan (Fayolle, 2007). Minat dan kemampuan berwirausaha adalah sesuatu yang bisa diajarkan dan seorang wirausaha bisa dibentuk melalui jalur pendidikan dan latihan. Pendidikan kewirausahaan dalam dua dekade terakhir ini telah mengalami pertumbuhan yang signifikan di sebagian besar negara industry (Matlay, 2008). Liñán (2004) mengklasifikasikan ada empat jenis program pendidikan kewirausahaan. Pertama, "Entrepreneurial Awareness Education", "Education for Start-Up" "Education for Entrepreneurial Dynamism", dan "Continuing Education for Entrepreneurs".

Liñán (2004) mengklasifikasikan ada empat jenis program pendidikan kewirausahaan. Pertama, "Entrepreneurial Awareness Education", bertujuan untuk meningkatkan pengetahuan tentang kewirausahaan dan untuk mempengaruhi sikap yang mungkin mempengaruhi niat. Kedua sebagai "Education for Start-Up" yang ditujukan pada orang-orang yang pada umumnya sudah memiliki ide kewirausahaan dan perlu memecahkan pertanyaan praktis bagaimana menjadi seorang entrepreneur. Ketiga, "Education for Entrepreneurial Dynamism", berfokus pada orang-orang yang sudah menjadi wirausahawan dan ingin mempromosikan perilaku dinamis setelah fase start-up. Keempat "Continuing Education for Entrepreneurs" menggambarkan program pembelajaran se-umur hidup dan berfokus pada entrepreneur yang sudah berpengalaman.

Seiring dengan berbagai jenis pendidikan kewirausahaan, ada empat alur penelitian penelitian pendidikan kewirausahaan antara lain (i) fokus pada peran program kewirausahaan pada individu dan masyarakat, (ii) berkaitan dengan sistemisasi program kewirausahaan, misalnya penggunaan lingkungan multimedia atau pengembangan kurikulum, (iii) meneliti isi dan penyampaiannya dalam program kewirausahaan; dan (iv) berkonsentrasi pada kebutuhan peserta individual dalam program kewirausahaan (Bechard et al., 2002).

Minat berwirausaha didefinisikan sebagai kesediaan individu untuk mewujudkan perilaku sebagai wirausaha, terlibat dalam kegiatan kewirausahaan, menjadi seorang wirausaha, atau membangun usaha baru (Mcstay, 2008; Dohse \& Walter, 2010). Menurut Bird (1988), minat berwirausaha mengacu pada pernyataan pemikiran secara individual dari seseorang yang ditujuan untuk menciptakan usaha baru, membangun konsep bisnis yang baru atau menciptakan nilai baru dalam perusahaan yang sudah ada.

Minat berwirausaha semakin diyakini sebagai sumber pembentukan formasi wirausaha dan pertumbuhan kewirausahaan di suatu negara. Kecenderungan mentalitas menghindari risiko dan berusaha mencari keamanan finansial sering menjadi penghambat tumbuhnya minat berwirausaha. Minat berwirausaha dalam hal ini diartikan sebagai kesediaan individu untuk mewujudkan perilaku sebagai wirausaha, terlibat dalam kegiatan kewirausahaan, menjadi seorang wirausaha, atau membangun usaha baru (Mcstay, 2008; Dohse \& Walter, 2010). Sementara itu faktor eksternal yang dapat mempengaruhi tumbuhnya minat berwirausaha adalah lingkungan keluarga, teman sebaya, pendidikan, dan sebagainya. Hal ini sejalan dengan hasil penelitian Indarti \& Rostiani (2008) yang berkesimpulan bahwa variabel kebutuhan akan pencapaian, efikasi diri, dan kesiapan instrumen seperti ketersediaan modal, jaringan sosial, dan akses informasi merupakan variabel dominan dalam mempengaruhi minat berwirausaha mahasiswa. 
Pembelajaran kewirausahaan di perguruan tinggi selama ini juga masih kurang dikaitkan dengan prinsip-prinsip dasar pengelolaan ekonomi yang diamanatkan oleh Undang-Undang Dasar Republik Indonesia 1945. Padahal roh yang terkandung dalam pasal 33 dan 34 relevan dengan karakter yang terdapat dalam caring economics yaitu mengedepankan kepentingan semua pihak berdasarkan semangat altruisme dan kompasionat dalam relasi sesama manusia dan manusia dengan lingkungannya menuju sasaran akhir pembangunan ekonomi nasional, yaitu meningkatkan kesejahteraan dan kemakmuran untuk mewujudkan kualitas kehidupan yang berkelanjutan (Witjaksono, 2016).

Selama ini paham neo liberal lebih dominan mewarnai wajah perekonomian dunia dalam membentuk perilaku manusia sebagai homo economicus. Sebagai sebuah tawaran gagasan alternatif pengelolaan ekonomi dalam masyarakat, akhir-akhir ini berkembang pemikiran tentang caring economics. Singer \& Richard (2015) dalam Witjaksono (2016) memaparkan tentang caring economics sebagai ilmu atau sistem ekonomi yang terkait dengan pentingnya caring. Sistem dan aksi ekonomi baru yang ditawarkan adalah yang berbasis "homo economicus as fundamentally pro-social being". Manusia ekonomi tetap menjadi watak dasar, namun orientasi tujuan akhirnya diarahkan untuk mencapai kemakmuran masyarakat dan lingkungannya (social well-being and environment prosperity).

Konsep caring economics juga datang dari Osch (2013) yang memaparkan bahwa caring economics lebih fokus pada isi, bentuk, organisasi, lembaga, atau kebijakan ekonomi yang menggeser paradigma ekonomi neo-liberal menjadi "caring for human being". Konsep dasar yang ditawarkan adalah menggeser paradigma berpikir ekonomi dari "homo economicus" menuju "caring for human being". Menurut pandangan ini, pendekatan dalam berpikir dan bertindak ekonomi diubah dari "menghimpun kekayaan untuk diri sendiri" menjadi "memakmurkan semua orang dan menjaga kelangsungan hidup di planet ini".

Sementara itu fenomena yang terjadi di lapangan adalah masih rendahnya minat menjadi seorang wirausaha di kalangan mahasiswa. Berdasarkan survey pendahuluan yang dilakukan terhadap 36 mahasiswa Program Studi Pendidikan Ekonomi Universitas Sanata Dharma, hanya sebesar 8 persen yang memiliki minat berwirausaha kategori tinggi, sebesar 47 persen memiliki minat berwirausaha sedang, dan pada kategori minat berwirausaha yang rendah sebesar 45 persen. Beberapa alasan dominan yang muncul terkait rendahnya minat berwirausaha ini antara lain tidak adanya kepastian akan meraih kesuksesan, adanya risiko kegagalan yang tinggi, dan penghasilan tidak menentu.

Untuk mengatasi permasalahan di atas perlu diimplementasikan model pembelajaran pendidikan kewirausahaan berbasis proyek yang mampu menumbuhkan minat berwirausaha mahasiswa. Pembelajaran berbasis proyek adalah model yang mengorganisasikan pembelajaran dalam sebuah proyek. Proyek merupakan tugas yang kompleks, didasarkan pada pertanyaan atau masalah yang menantang, melibatkan siswa dalam mendesain perencanaan, pemecahan masalah, pengambilan keputusan, atau kegiatan investigasi; memberikan siswa kesempatan untuk bekerja relatif mandiri dalam jangka lebih waktu yang lama; dan berujung pada penciptaan produk nyata atau presentasi (Jones et al., 1997).

\section{METODE}

Metode penelitian yang digunakan dalam penelitian ini adalah kuasi eksperimen atau eksperimen semu. Jenis penelitian ini menggunakan seluruh subjek dalam kelompok belajar untuk diberi perlakuan (treatment), tidak menggunakan subjek yang diambil secara acak. Penelitian ini dilakukan pada satu kelompok mahasiswa (kelompok eksperimen) tanpa adanya kelompok 
pembanding (kelompok kontrol). Desain penelitian ini dipilih untuk melihat adanya peningkatan minat berwirausaha mahasiswa sebelum dan sesudah perlakuan diimplementasikan.

Subjek dalam penelitian ini adalah mahasiswa Program Studi Pendidikan Ekonomi Fakultas Keguruan dan Ilmu Pendidikan Universitas Sanata Dharma yang sedang menempuh Mata Kuliah Pendidikan Kewirausahaan sejumlah 30 orang mahasiswa. Sementara objek penelitiannya adalah minat berwirausaha mahasiswa. Data minat berwirausaha dikumpulkan dengan teknik kuesioner. Kuesioner terdiri dari pernyataan antara lain: (i) kesiapan menjadi seorang entrepreneur yang peduli kepada sesama dan lingkungan, (ii) memiliki tujuan sebagai seorang entrepreneur, (iii) niat untuk memulai dan menjalankan usaha secara mandiri, (iv) tekad membangun usaha yang menjawab permasalahan sosial ekonomi dan pendidikan, dan (v) keseriusan memikirkan membangun usaha.

Pada tahap persiapan pembelajaran di kelas eksperimen, dosen membuat perencanaan terkait skenario pembelajaran yang berbasis proyek. Perangkat pembelajaran yang dipersiapkan antara lain silabus, satuan acara perkuliahan, materi pembelajaran, lembar kerja mahasiswa, dan daftar kegiatan mahasiswa. Penyusunan instrumen ini didahului dengan pengamatan terhadap situasi mahasiswa yang akan dijadikan subyek penelitian. Teknik pengumpulan data yang dipergunakan dalam penelitian ini antara lain: (i) observasi yang meliputi pengamatan dan pencatatan setiap kejadian secara mendetail. (ii) Dokumentasi dengan mempelajari arsip-arsip yang dimiliki oleh dosen, misalnya catatan tentang sikap mahasiswa, nilai tes, presensi kelas, keaktifan di kelas, dan sebagainya. Dalam penelitian ini hipotesis yang diajukan yaitu adanya peningkatan minat berwirausaha mahasiswa setelah mengikuti perkuliahan kewirausahaan berbasis caring economics.

\section{HASIL DAN PEMBAHASAN}

Penelitian kuasi eksperimen diawali dengan kegiatan perencanaan proses pembelajaran yang menerapkan Project Based Learning. Minat berwirausaha mahasiswa menunjukkan bahwa sebanyak 3 responden (10 persen) yang termasuk dalam kategori tinggi dan meningkat menjadi 9 responden (30 persen) setelah mengikuti proses pembelajaran. Responden yang termasuk dalam kategori sedang sebanyak 9 responden (30 persen) dan meningkat menjadi 17 orang (56 persen) setelah mengikuti proses pembelajaran. Sementara itu terjadi penurunan jumlah responden yang berada dalam kategori rendah yaitu sebelum mengikuti pembelajaran sejumlah 18 responden (60 persen) dan menurun menjadi 4 orang (14 persen) setelah mengikuti proses pembelajaran (Tabel 1).

Tabel 1. Karakteristik Minat Berwirausaha Mahasiswa Sebelum dan Sesudah Perlakuan

\begin{tabular}{lcccc}
\hline Karakteristik & \multicolumn{2}{c}{ Sebelum Perlakuan } & \multicolumn{2}{c}{ Sesudah Perlakuan } \\
\cline { 2 - 5 } & Jumlah & Persentase & Jumlah & Persentase \\
\hline Tinggi & 3 & 10 & 9 & 30 \\
Sedang & 9 & 30 & 17 & 56 \\
Rendah & 18 & 60 & 4 & 14 \\
\hline
\end{tabular}

Berdasarkan analisis deskriptif pada tabel 1, sebelum perlakukan, mayoritas mahasiswa memiliki minat berwirausaha rendah dengan persentasi sebesar $60 \%$. Setelah adanya perlakuan, proporsi minat berwirausaha bergeser menjadi sebesar 56\% mahasiswa memiliki minat berwirausaha sedang. Selain itu, minat berwirausaha tinggi pada sebelum perlakukan hanya $10 \%$ sedangkan setelah perlakuan meninggat menjadi 30\%. Maka hasil observasi yang dilakukan sebelum dan sesudah proses pembelajaran dapat dikatakan meningkat. 
Tabel 2. Statistik Deskriptif Minat Berwirausaha Mahasiswa

\begin{tabular}{cccc}
\hline Variabel & Mean & Std. Deviation & Std. Error Mean \\
\hline Sebelum Uji Efektifitas & 4,27 & 1,507 &, 275 \\
Sesudah Uji Efektifitas & 5,60 & 1,276 &, 233 \\
\hline
\end{tabular}

Hasil olah data uji beda terhadap variabel minat berwirausaha menunjukkan bahwa terdapat perbedaan yang signifikan antara minat berwirausaha mahasiswa pada saat sebelum dan sesudah proses pembelajaran. Skor variabel minat berwirausaha mahasiswa sebelum proses pembelajaran sebesar 4,27 sedangkan sesudah proses pembelajaran sebesar 5,60 (Tabel 2). Kedua rerata ini memiliki perbedaan signifikan pada alpha 5 persen dengan tingkat signifikansi 0,000 (sig 2-tailed) seperti tertera pada Tabel 3). Hal ini berarti minat berwirausaha mahasiswa mengalami peningkatan dengan diterapkannya pembelajaran kewirausahaan berbasis caring economics.

Tabel 3. Uji Beda Minat Berwirausaha Mahasiswa

\begin{tabular}{cccc}
\hline \multicolumn{1}{c}{ Variabel } & t & df & Sig. (2 tailed) \\
\hline $\begin{array}{l}\text { sebelum uji efektifitas - } \\
\text { sesudah uji efektifitas }\end{array}$ & $-5,637$ & 29 &, 000 \\
\hline
\end{tabular}

Dalam proses pembelajaran yang menerapkan project based learning ini mahasiswa menjalankan beberapa kegiatan secara berkelompok. Kegiatan dimulai dengan melakukan observasi pada lingkungan sekitar tempat tinggal atau kampus untuk mengamati kegiatan bisnis yang ada dan menemukan adanya permasalahan sosial, ekonomi, dan pendidikan di sekitarnya. Setiap kelompok diminta melakukan wawancara mendalam dengan para pelaku usaha untuk menggali informasi terkait awal mula ketertarikan para pelaku usaha menjalankan bisnisnya. Selanjutnya mahasiswa diminta membuat laporan tertulis hasil observasi tersebut dan mempresentasikan di kelas. Tahap selanjutnya setiap kelompok diminta membuat sebuah rancangan usaha kreatif yang dapat dilakukan untuk ikut serta mengatasi adanya masalah sosial, ekonomi dan pendidikan di masyarakat. Pada akhir eksperimen mahasiswa diminta merefleksikan apa yang telah dilakukan dalam proyek tersebut. Secara umum mahasiswa merasa terbantu untuk dapat mengenali potensi yang ada dalam dirinya sehingga dapat menumbuhkan minat mahasiswa untuk berwirausaha.

Proses pembelajaran kewirausahaan memang seharusnya didesain secara khusus untuk memfasilitasi para penduduk usia muda untuk mengembangkan potensi dalam berwirausaha. Hal ini didasarkan pada keyakinan bahwa kewirausahaan sebenarnya adalah seni yang bisa dipelajari dan dikembangkan (Fayolle, 2007; Khalifa \& Dhiaf, 2016; Barba-Sánchez \& Atienza-Sahuquillo, 2018; Fayolle \& Gailly, 2015). Pengalaman Jerman dalam pendidikan kewirausahaan menunjukkan hasil yang baik. Seluruh kerangka kurikulum untuk Vocational Education and Training (VET) dirancang oleh Kultusministerkonferenz (Standing Conference of Education Minister) yang mensyaratkan seluruh sekolah kejuruan harus memberikan wawasan atas berbagai jenis pekerjaan termasuk kewirausahaan guna untuk mendukung karir dan kehidupan perencanaan berwirausaha (European Commission, 2009). Hasil ini mendukung pendapat yang menyatakan bahwa minat dan kemampuan berwirausaha adalah sesuatu yang bisa diajarkan dan seorang wirausaha bisa dibentuk melalui jalur pendidikan dan latihan (European Commission, 2015).

Pengembangan pembelajaran kewirausahaan terbukti dapat meningkatkan minat berwirausaha mahasiswa. Para mahasiswa merasa terbantu untuk dapat menemukan potensi dirinya sekaligus menggugah semangat untuk menekuni bidang wirausaha khususnya wirausaha sosial. Hal ini juga sejalan dengan temuan penelitian sebelumnya oleh Darmawan \& Soetjipto 
(2016). Minat berwirausaha semakin diyakini sebagai sumber pembentukan formasi wirausaha dan pertumbuhan kewirausahaan di suatu negara. Bahkan dampak lanjutan dari berkembangnya minat berwirausaha akan menjadi sumber pertumbuhan ekonomi dan kesejahteraan masyarakat. Sementara itu pengalaman di berbagai negara tidak cukup banyak yang sejak dini memang berminat menjadi seorang wirausaha. Kecenderungan mentalitas menghindari risiko dan berusaha mencari keamanan finansial sering menjadi penghambat tumbuhnya minat berwirausaha. Minat berwirausaha dalam hal ini diartikan sebagai kesediaan individu untuk mewujudkan perilaku sebagai wirausaha, terlibat dalam kegiatan kewirausahaan, menjadi seorang wirausaha, atau membangun usaha baru (Dohse \& Walter, 2010; Mcstay, 2008; Farouk et al., 2014; Hattab, 2014; Khalifa \& Dhiaf, 2016).

Sementara itu faktor eksternal yang dapat mempengaruhi tumbuhnya minat berwirausaha adalah lingkungan keluarga, teman sebaya, pendidikan, dan sebagainya. Hal ini sejalan dengan hasil penelitian Indarti \& Rostiani (2008) yang berkesimpulan bahwa variabel kebutuhan akan pencapaian, efikasi diri, dan kesiapan instrumen seperti ketersediaan modal, jaringan sosial, dan akses informasi merupakan variabel dominan dalam mempengaruhi minat berwirausaha mahasiswa. Faktor pendidikan yang dirancang terbukti dapat meningkatkan entrepreneurial intention di banyak tempat (Tentama et al., 2019; Rani et al., 2019).

Mahasiswa yang telah mengikuti proses pembelajaran akhirnya memahami tujuan profesional dari seorang entrepreneur dan menyatakan siap untuk menjadi seorang entrepreneur yang peduli terhadap sesama dan lingkungan. Mereka pada umumnya menyatakan tekadnya untuk membangun usaha yang menjawab persoalan sosial ekonomi dan pendidikan di masyarakat kelak kemudian hari. Dalam rencana mereka yang akan datang sebagian ada yang berminat bekerjasama dengan keluarga atau teman untuk membangun usaha yang dirancang.

Melalui pendidikan kewirausahaan yang baik akan memberikan peluang tumbuh dan berkembangnya potensi kreativitas dan inovasi peserta didik. Nilai-nilai kewirausahaan akan menjadi karakteristik peserta didik yang dapat digunakannya dalam bersosialisasi dan berinteraksi dengan lingkungannya. Pada akhirnya pribadi yang memiliki karakter kreatif, inovatif, bertanggung jawab, disiplin dan konsisten akan mampu memberikan kontribusi dalam pemecahan masalah sosial ekonomi dan pendidikan yang ada di Indonesia.

\section{SIMPULAN}

Melalui penelitian ini terbukti bahwa minat berwirausaha mahasiswa dapat ditumbuhkan melalui pendidikan kewirausahaan berbasis caring economics. Para mahasiswa merasa sangat terbantu untuk dapat menemukan potensi dirinya sekaligus menggugah semangat untuk menekuni bidang wirausaha. Proses pembelajaran yang dilakukan dengan memasukkan aspek caring economics skenario pembelajaran dapat menumbuhkan rasa kepedulian terhadap sesama dan lingkungan dalam semangat kerjasama dan gotong royong.

Beberapa temuan pokok dalam penelitian ini terkait dengan pengembangan minat berwirausaha mahasiswa antara lain: mahasiswa memiliki kesadaran untuk mewujudkan karakter wirausaha dalam dirinya, adanya pengakuan keyakinan diri yang kuat bahwa dapat membangun usaha, dan memiliki motivasi yang kuat untuk membangun usaha di bidang social entrepreneurship baik bersama keluarga maupun teman.

Peneliti selanjutnya dapat mengimplementasi berbagai model pembelajaran untuk aspek-aspek lain dalam pendidikan kewirausahaan berbasis caring economics misalnya ide dan peluang usaha, studi kelayakan usaha, merancang produk, merancang pemasaran, dan lain-lain. Dengan demikian pembelajaran pendidikan kewirausahaan pada jenjang perguruan tinggi akan semakin 
kaya dengan pembelajaran yang berbasis penelitian dan semakin meningkatkan minat mahasiswa untuk berwirausaha.

\section{DAFTAR PUSTAKA}

Barba-Sánchez, V., \& Atienza-Sahuquillo, C. (2018). Entrepreneurial intention among engineering students: The role of entrepreneurship education. European Research on Management and Business Economics, 24(1), 53-61. https://doi.org/10.1016/j.iedeen.2017.04.001

Bechard, J., Gregoire, D., \& Grégoire, D. (2002). Entrepreneurship Education Revisited : The Case of Higher Education. Academy of Management Learning and Education, 4(September), 840853.

http://citeseerx.ist.psu.edu/viewdoc/download?doi=10.1.1.461.92\&rep=rep1\&type=pdf

Bird, B. (1988). Implementing Entrepreneurial Idea: The Case for Intention (p. Volume 13 Number 3 pages 442-453). Academy of Management Review. https://doi.org/https://doi.org/10.5465/amr.1988.4306970

Darmawan, I., \& Soetjipto, B. E. (2016). The implementation of project-based learning to improve entrepreneurial intention and entrepreneurship learning outcome of economics education students. Journal of Business and Management, 18(10), 98-102. https://doi.org/10.9790/487X18100798102

Dohse, D., \& Walter, S. G. (2010). The role of entrepreneurship education and regional Context in forming entrepreneurial intentions (Working Paper Present at Document de Treball de IIEB). https://hdl.handle.net/10419/59753

European Commission. (2009). Entrepreneurship in Vocational Education and Training. 1-46.

European Commission. (2015). Entrepreneurship education: a road to success. A compilation of evidence on the impact of entrepreneurship education strategies and measures. In Belgium, European Commission (Vol. 115).

Farouk, A., Ikram, A., \& Sami, B. (2014). The Influence of Individual Factors on the Entrepreneurial Intention. International Journal of Managing Value and Supply Chains, 5(4), 4757. https://doi.org/10.5121/ijmvsc.2014.5404

Fayolle, A. (2007). Handbook of Research in Entrepreneurship Education: Volume 2. Edward Elgar Publising, Inc. https://doi.org/10.1108/17506200810861276

Fayolle, A., \& Gailly, B. (2015). The impact of entrepreneurship education on entrepreneurial attitudes and intention: Hysteresis and persistence. Journal of Small Business Management, 53(1), 75-93. https://doi.org/10.1111/jsbm.12065

Hattab, H. W. (2014). Impact of Entrepreneurship Education on Entrepreneurial Intentions of University Students in Egypt. Journal of Entrepreneurship, 23(1), 1-18. https://doi.org/10.1177/0971355713513346

Indarti, N., \& Rostiani, R. (2008). Intensi Kewirausahaan Mahasiswa: Studi Perbandingan Antara Indonesia, Jepang Dan Norwegia. Jurnal Ekonomi \& Bisnis Indonesia (Fakultas Ekonomi Dan Bisnis Universitas Gadjah Mada), 23(4), 369-384. https://doi.org/10.22146/jieb.6316

Jones, B., Rasmussen, C., \& Moffitt, M. (1997). Real-Life Problem Solving: A Collaborative approach to interdisciplinary learning. American Psychological Association.

Khalifa, A. H., \& Dhiaf, M. M. (2016). The Impact of Entrepreneurship Education on Entrepreneurial Intention: The UAE Context. Polish Journal of Management Studies, 14(1), 119-128. https://doi.org/10.17512/pjms.2016.14.1.11

Liñán, F. (2004). Intention-based models of entrepreneurship education. Piccola Impresa / Small Business, 2004(3), 11-35. 
Matlay, H. (2008). The impact of entrepreneurship education on entrepreneurial outcomes. Journal of Small Business and Enterprise Development, 15(2), 382-396. https://doi.org/10.1108/14626000810871745

Mcstay, D. (2008). An investigation of undergraduate student self-employment intention and the impact of entrepreneurship education and previous entrepreneurial experience Presented By [School of Business University The Australia]. https://pure.bond.edu.au/ws/portalfiles/portal/18371119

Osch, T. van. (2013). Towards a Caring Economic Approach. May, 1-29.

Rani, N. S. A., Krishnan, K. S., Saidun, Z., \& Ahmad, H. (2019). The relationship between entrepreneurship education and entrepreneurial intention of Universiti Kuala Lumpur teknoputra alumni. Humanities and Social Sciences Reviews, 7(1), 147-155. https://doi.org/10.18510/hssr.2019.7118

Tentama, F., Mulasari, S. A., Subardjo, \& Widiasari, S. (2019). Entrepreneurship education to improve entrepreneurship intention. Humanities and Social Sciences Reviews, 7(3), 162-168. https://doi.org/10.18510/hssr.2019.7325

Witjaksono, M. (2016). Analisis Kritis dan Pragmatis Caring Economics sebagai Paradigma baru Kajian Ekonomi. Jurnal Ekonomi Dan Ekonomi Studi Pembangunan, 8(2), 217-244. https://doi.org/10.17977/um002v8i22016p217 